Volume 11

Number 2 Fall 2020

Article 4

$9-30-2020$

\title{
Carl Philipp Emanuel Bach: A Composer on the Fault Line of Ideological Change
}

Stephen J. White

Cedarville University, stephenwhite@cedarville.edu

Follow this and additional works at: https://digitalcommons.cedarville.edu/musicalofferings

Part of the Ethnomusicology Commons, Fine Arts Commons, Musicology Commons, Music Performance Commons, and the Music Theory Commons

\section{Recommended Citation}

White, Stephen J. (2020) "Carl Philipp Emanuel Bach: A Composer on the Fault Line of Ideological Change," Musical Offerings: Vol. 11 : No. 2 , Article 4.

DOI: 10.15385/jmo.2020.11.2.4

Available at: https://digitalcommons.cedarville.edu/musicalofferings/vol11/iss2/4 


\title{
Carl Philipp Emanuel Bach: A Composer on the Fault Line of Ideological Change
}

\section{Document Type}

Article

\begin{abstract}
While there has been a renewed interest in recent years on Carl Philipp Emanuel Bach and his place as a transitional figure in Western music history, little academic thought is given to his musical philosophy. Emanuel's father, Johann Sebastian Bach, taught him the German-Protestant view that the primary purpose of music was to highlight scripture. Through his education, Emanuel gained an appreciation for the secular philosophies of humanism and the Enlightenment. In contrast to J. S. Bach's Protestant views, the philosophies of the Enlightenment asserted that the primary purpose of music was to highlight the essence of humanity through emotions and reasoning. During his many years of working with Frederick the Great, Emanuel developed his musical style as he was influenced by many Enlightenment philosophers and musicians, primarily René Descartes and Jean-Philippe Rameau. Emanuel's use of the Empfindsamer Stil in music expanded the Enlightenment musical philosophy of the Doctrine of Affections by representing the unstable nature of human emotion. Emanuel's Versuch über die wahre art das clavier zu spielen was not only a profound declaration of musical theory technique but also demonstrated his belief that music should be guided by emotion.
\end{abstract}

\section{Keywords}

C. P. E. Bach, Enlightenment, Musical Philosophy, Frederick the Great, Empfindsamer Stil, Doctrine of Affections

\section{Creative Commons License}

\section{(c)}

This work is licensed under a Creative Commons Attribution-Noncommercial-No Derivative Works 4.0 License. 


\title{
Carl Philipp Emanuel Bach: A Composer on the Fault Line of Ideological Change
}

\author{
Stephen J. White \\ Cedarville University
}

W hile there has been a renewed interest in recent years on Carl Philipp Emanuel Bach and his place as a transitional figure in

Western music history, little academic thought is given to his musical philosophy. Emanuel's father, Johann Sebastian Bach, taught him the German-Protestant view that the primary purpose of music was to highlight scripture. Through his education, Emanuel gained an appreciation for the secular philosophies of humanism and the Enlightenment. In contrast to J. S. Bach's Protestant beliefs, the philosophies of the Enlightenment asserted that the primary purpose of music was to highlight the essence of humanity through emotions and reasoning. During his many years of service to Frederick the Great, Emanuel developed his musical style and was influenced by Enlightenment philosophers and musicians, primarily René Descartes and Jean-Philippe Rameau. Emanuel's use of the Empfindsamer Stil in music expanded the Enlightenment musical philosophy of the Doctrine of Affections by representing the unstable nature of human emotion. Emanuel's Versuch über die wahre art das clavier zu spielen was not only a profound declaration of musical technique but also showed his belief that music should be guided by emotion. Carl Philipp Emanuel Bach's philosophical approach to music was partially influenced by his German-Protestant upbringing and ultimately echoed the Enlightenment view of music as an expression of human emotion, as exemplified through his use of the Empfindsamer Stil.

\section{Emanuel's Religious, Musical, and Secular Education}

An individual's philosophical outlook is shaped by their surroundings and upbringing. Likewise, a composer's musical style is shaped by their

Musical Offerings 11, no. 2 (2020): 83-97

ISSN 2330-8206 (print); ISSN 2167-3799 (online)

(C) 2020, Stephen J. White, licensed under CC BY-NC-ND

(http://creativecommons.org/licenses/by-nc-nd/4.0/) 
heritage and education. In his approach to music, Carl Philipp Emanuel Bach was greatly impacted by his upbringing in the Bach family. Emily Daymond describes the musical heritage of the Bach family, stating, "For generations, from the time of Veit Bach about 1555, [the Bach family] had been musicians, so well known that at one time town musicians in Erfurt were called 'Bachs,' whether they included any of the family or not." "Growing up in the Bach household, Emanuel was constantly exposed to the leading musicians of the day because many of them would visit Leipzig and, in turn, meet the Bach family. HansGünter Ottenberg stated this clearly in his biography, C. P. E. Bach.

For some time the German musical world had been showing increasing interest in the 'great composer and organist' Johann Sebastian Bach; thus, his son was able to write in his autobiography: "I had from an early age the special good fortune of hearing the most excellent music of all kinds all around me, and of making the acquaintance of many first-rate masters, some of whom became my friends."

These visiting musicians, with whom he interacted from a young age, helped Emanuel to grow musically and exposed him to various outlooks on musical style. Having had his father as his instrumental and composition teacher, Emanuel learned exemplary skills both on keyboard instruments through studies like the Well-Tempered Clavier and in compositional studies from the Clavierbüchlein. ${ }^{3}$

J. S. Bach taught Emanuel the importance of high-quality music as a method of worship. J. S. Bach's core tenet of musical philosophy was based upon this idea. He saw that music had the power to affect one's emotions and that it was a vital tool for the church. Much of the Lutheran church music of his time was written in a simple and unassuming way, but J. S. Bach believed that using more complex methods of composition could enhance church music's emotional power, thereby pointing listeners toward Christ and aiding the message of biblical text. He had learned this perspective from his Lutheran heritage, as Martin Luther had

\footnotetext{
${ }^{1}$ Emily R. Daymond, "Carl Philipp Emanuel Bach," Proceedings of the Musical Association, no. 33 (1906-1907): 45. doi:10.1093/jrma/33.1.45.

${ }^{2}$ Hans-Günter Ottenberg, C. P. E. Bach (New York: Oxford University Press, 1987), 13.

${ }^{3}$ Ibid., 13-14.
} 
a vast sphere of influence in the German lands where the Bachs resided. ${ }^{4}$ Luther recognized music's potential to display God's glory and its ability to highlight scripture. He believed that music could directly relate scriptural messages to the people without the need of a priest. This belief stemmed from Luther's Protestant theology which stated that man could communicate with God without the intercession of priests and showed the importance of scripture as the sole basis for doctrine.

It can be understood with certainty that J. S. Bach believed in the power of music to highlight scripture and bring man closer to God. This claim is supported by one of his own commentaries, in which he underlined the passage, "Wherever music is made, God in his mercy is present." With this approach, J. S. Bach demonstrated music's ability to affect one's emotions in the context of worship. According to James R. Gaines in Evening in the Palace of Reason, "From his first job in Arnstadt, Bach had worked with the words of Luther and the Bible virtually every day of his career, and as he grew older his pursuit of spiritual understanding became ever more gripping." ${ }^{\prime \prime} \mathrm{J}$. S. Bach saw music not just as a means of human expression, but as a higher calling which could influence its audience for God's glory.

While he did compose during the era of Enlightenment, J. S. Bach chose not to involve himself in philosophical discussions. Due to the integration of emotional depth, much of his music can be explained by philosophies such as the Doctrine of Affections, which highlighted music's ability to influence and be influenced by the soul and human emotion. Through lyrical melodies, his chorale preludes express greater emotion than would be expected from a Protestant composer during the Baroque era. While many Protestants of the time allowed the religious zeal to negate the need for passion in music, J. S. Bach saw music's potential to touch man's soul. ${ }^{7}$ However, the Doctrine of Affections also stated that music could be a display or dictation of a particular human

\footnotetext{
${ }^{4}$ Robert L. Marshall, "Truth and Beauty: J. S. Bach at the Crossroads of Cultural History," Bach 21, no. 2 (Summer 1990): 4-5. http://www.jstor .org/stable/41640340.

${ }^{5}$ Otto L. Bettmann, "Bach the Rhetorician," American Scholar 55, no. 1 (Winter 1986): 116. http://www.jstor.org/stable/41211296.

${ }^{6}$ James R. Gaines, Evening in the Palace of Reason: Bach Meets Frederick the Great in the Age of Enlightenment (New York: HarperCollins, 2005), 169.

${ }^{7}$ Paul Henry Lang, "Bach: Artist and Poet," in Musicology and Performance, ed. Alfred Mann and George J. Buelow (New Haven, CT: Yale University Press, 1997), 68-71.
} 
emotion and attempted to explain music solely as a means of human expression. Most Protestant music of the time conflicts ideologically with the Doctrine of Affections and similar philosophies because Protestants believed that music was a gift from God. Therefore, it could only rightly portray scriptural truth, not human emotion. Because of this orthodox view of music, J. S. Bach never attempted to portray human emotion explicitly or align with philosophical discord of his times. While he did recognize the emotional power of music, he believed that music was meant as an expression of emotion and admiration toward God, and not merely for entertainment or human edification. ${ }^{8}$

Emanuel, like his father, recognized music's emotional power and received, in part, his father's philosophy that music is a powerful tool given by God to show his glory. However, he attempted to highlight the emotionality of music in other ways, resulting in a musical style vastly different from that of J. S. Bach. Daymond states, "[Emanuel] inherits Sebastian Bach's emotional, mystical nature; he is in full sympathy with it, but he will try to make it speak through another language - the language of harmonic form. " Emanuel, instead of using the thick texture and baroque conventions of his father to drive music, chose to use harmony. He employed light harmonic chords with modern chromatic progressions to heighten the power and text of his many sacred musical compositions, such as his twenty-two settings of the Passion story. ${ }^{10}$ This focus on the emotional drive of music showcases Emanuel's interest in the Doctrine of Affections, a key tenet of Enlightenment musical philosophy which led musical composition in Europe during the seventeenth and eighteenth centuries. ${ }^{11}$ By recognizing music's ability to influence emotions in sacred settings and beyond, Emanuel was able to use music to honor his German-Protestant background while ushering in the more emotional and humanistic ideals of the Enlightenment.

Along with his musical education, Emanuel's general education also affected his musical philosophy. Emanuel attended the Saint Thomas School of Leipzig where his father taught as a cantor. This school combined musical training with a humanistic foundation. He was taught rhetoric and grammar through studying classical literature and also learned history, geography, and mathematics. Emanuel was greatly

\footnotetext{
${ }^{8}$ Marshall, "Truth and Beauty," 5.

${ }^{9}$ Daymond, "Carl Philipp Emanuel Bach," 48.

${ }^{10}$ Ibid., 51.

${ }^{11}$ Paul Henry Lang, "The Enlightenment and Music," Eighteenth-Century

Studies 1, no. 1 (Autumn 1967): 96. doi:10.2307/3031668.
} 
influenced by his teacher, Johann Matthias Gesner, at Saint Thomas. Gesner introduced Emanuel and his peers to enlightened philosophical ideals through humanistic education. ${ }^{12}$ This education opened Emanuel's eyes to a new way of thinking, in which man and reasoning became the key to creativity and knowledge.

Emanuel chose to further his education by attending law school at the University of Leipzig. During this time, Emanuel prioritized his studies over music. This is made evident by the fact that he had no formal musical occupation during this time, other than a job tuning harpsichords. When he went on to continue his studies at the University of Frankfurt, Emanuel began composing and directing music in his free time. While in Frankfurt, he soon became more dedicated to music, eventually making it his primary vocation. ${ }^{13}$ Emanuel may have chosen to continue his law studies in hope of finding musical patronage. His studies gave him the opportunity to market his musical talents to the Prussian nobility by directing local choral and instrumental ensembles in honor of the local ruling Hohenzollern family. After making a name for himself among the nobility in Frankfurt, Emanuel moved to Berlin where he found patronage under Enlightenment figure King Frederick II of Prussia. ${ }^{14}$ Following his robust education in secular humanist studies, it is apparent that Emanuel moved away from his German-Protestant background and grew increasingly involved in the Enlightenment.

\section{Musical Philosophy in the Era of Enlightenment}

Emanuel Bach lived during a time of great philosophical discussion, and it is obvious that he was listening to and learning from European society. From the time of his education at St. Thomas School and onward, Emanuel was immersed in the humanistic ideals that were blending into a new era known as the Enlightenment. ${ }^{15}$

The Enlightenment, which began during the late Baroque Era, stemmed from the ideals of humanism. With humanism, there was a great emphasis on rationalizing music by showing the mathematical and scientific properties and proportions of melody and harmony. During the Enlightenment, some musical composers and theorists continued to view

12 Ottenberg, C. P. E. Bach, 11-12.

${ }^{13}$ Daymond, "Carl Philipp Emanuel Bach," 45-46.

${ }^{14}$ David Schulenberg, The Music of Carl Philipp Emanuel Bach, Eastman Studies in Music (Rochester, NY: University of Rochester Press, 2014), 3.

15 Ottenberg, C. P. E. Bach, 11. 
music in terms of proportions, but ideas about musical philosophy and emotion became prevalent. Thus, the Enlightenment was not a full departure from the former mathematical approach to music, but instead centered on the balance between emotions and rationality. ${ }^{16}$ In terms of the philosophy of emotions, the musical Enlightenment was centered around two core tenets: imitation and affections. Paul Henry Lang explains the first tenet in the following way.

Music is an art of motion in time, and as such it is akin to the motions of the human soul, from which it follows that music is able to apprehend and convey the impulses and moods of the human soul. In a word, it is an art of imitation. ${ }^{17}$

While seeing music as an art of imitation was a core philosophy of the Enlightenment, the tenet of music as a process of the affections is often considered more vital. This process is fittingly displayed in Die Affektenlehre or the Doctrine of Affections. This doctrine centered around the idea that music directly correlates to human emotion. Therefore, human emotion and mental states could dictate musical composition and were directly displayed in the music itself. Human affection could be displayed through various keys, meters, melodic figures, harmonic progressions, and rhythmic passages. This doctrine rationally explained emotion by assuming that music must represent one emotion at a time in a rational or proportional manner. ${ }^{18}$ The Doctrine of Affections was heavily based on seventeenth-century philosopher Descartes's works Compendium musicae and Traité des passions de l'âme. In these works, Descartes explained that in music, large, open intervals could typify happy emotions, and smaller, closed intervals could represent sad emotions. While this notion was not revolutionary, Descartes was the first person to ever rationalize these ideas and to categorize them. ${ }^{19}$ The Doctrine of Affections clearly took its place at the forefront of Enlightenment musical philosophy. This idea of music representing emotion is likely one of the most important and longest lasting philosophies of the Enlightenment.

Although music was heavily based on emotions, many Enlightenment thinkers recognized that music must have a rational foundation.

\footnotetext{
${ }^{16}$ Lang, "Enlightenment and Music," 93-95.

17 Ibid., 96.

18 Ibid.

${ }^{19}$ Ibid., 101.
} 
Consequently, the Enlightenment saw a continued interest in writings on music theory and practice, which had begun with humanism. Rameau strongly believed that music should be created through reason and logical process, and not simply as a result or display of emotion. In his eyes, music was a process that could only be described using musical terms; any other explanation was pure fantasy and illogical. ${ }^{20} \mathrm{He}$ is best remembered for writing a four-volume collection of his research on tonal harmony with musical applications known as Traité de l'harmonie (Treatise on Harmony). ${ }^{21}$ In his book, Rameau demonstrates that music is based on concurrent patterns and combinations of notes. Therefore, his aim in the book is to discover formulas through which music can be broken down. These formulas were based on note patterns and combinations which he had observed on a macro level both musically and scientifically. ${ }^{22}$ Rameau and his treatise demonstrate the importance of rational explanations for music in the Enlightenment. They exemplify the idea that, for many, reasoning was the key to music.

Emanuel developed his own musical philosophy substantially during his tenure in Frederick's court. Because of his position both as a political leader and as a societal leader in Europe, Frederick surrounded himself, Emanuel, and their collogues with the leading musicians and scholars of the day. One of these intellectuals was French philosopher and musical theorist Jean le Rond d'Alembert. ${ }^{23}$ D'Alembert's work was heavily based on the work of Rameau. According to D'Alembert,

\begin{abstract}
[Rameau] has reflected with much success on the theory of this same art; that he has found, in the fundamental bass, the principle of harmony and of melody; that by this means he has reduced to simpler and more certain laws a science confined before him to arbitrary rules, or [rules] dictated by blind experiment. ${ }^{24}$
\end{abstract}

\footnotetext{
${ }^{20}$ Lang, "Enlightenment and Music," 103.

${ }^{21}$ Julien Tiersot and Theodore Baker, "Rameau," Musical Quarterly 14, no. 1

(January 1928): 82. doi:10.1093/mq/xiv.1.77.

22 Ibid., 86.

${ }^{23}$ Shiru Lim, "Frederick the Great and Jean Le Rond D'Alembert on Philosophy, Truth, and Politics," Historical Journal 61, no. 2 (June 2018): 360-361. doi:10.1017/s0018246x17000310.

${ }^{24}$ Jonathan W. Bernard and Jean-Philippe Rameau, "The Principle and the Elements: Rameau's 'Controversy with D'Alembert,'" Journal of Music Theory 24, no. 1 (Spring 1980): 38. doi:10.2307/843738.
} 
Because he was a scientific theorist, D'Alembert appreciated Rameau's approach of rationalizing and categorizing music. Inspired by Rameau's Mémoire, which outlined the basis of his Traité de l'harmonie, D'Alembert wrote Elémens de musique, théorique et pratique, suivant les principes de M. Rameau (Elements of Theoretical and Practical Music, Following the Principles of M. Rameau). In this work, he built upon Rameau's musical theories by further explaining and clarifying them. D'Alembert was undeniably influenced by Rameau in his scientific approach to music theory, highlighting the rational side of Enlightenment musical philosophy. ${ }^{25}$ Through this rational approach to music, D'Alembert represented the logical side of the Enlightenment debate surrounding the balance of emotion and logic - a debate in which Frederick and Emanuel were immersed. Emanuel clearly took note of the rational side of Enlightenment musical thought, as is evident in his extensive writings on keyboard technique and artistry. However, more important to Emanuel than logic and proportionality was the connection between emotions and music expanding the Enlightenment ideals set forth by Descartes.

\section{The Enlightenment Music and Writings of Emanuel Bach}

Emanuel was a key member of Enlightenment musical society through both his music and his musical writings, and he championed the ideal of emotionality in music. He expanded upon the Enlightenment philosophy of the Doctrine of Affections through the Empfindsamer Stil in many of his compositions. He also wrote on musical theory as in Versuch über die wahre art das clavier zu spielen (Essay on the True Art of Playing Keyboard Instruments) in a way that highlighted emotions as paramount to proper keyboard playing.

The Empfindsamer Stil, a principle which he utilized in several of his works, is the chief example of Emanuel's Enlightenment philosophy. The Empfindsamer Stil was a musical style which arose from of Enlightenment thinking and translates to "sensitive style." This word comes from the root Empfindsamkeit, which was a descriptor of having sensitivity in viewing both beautiful and harsh aspects of society. ${ }^{26}$ Timothy Corrao explains this in relation to music: "Those who championed Empfindsamkeit argued that human emotions are not

${ }^{25}$ Bernard and Rameau, "Principle and the Elements," 37-38.

${ }^{26}$ Georgia Cowart, "Critical Language and Musical Thought in the Seventeenth and Eighteenth Centuries," College Music Symposium 27 (1987):

23. http://www.jstor.org/stable/40373840. 
isolated phenomena, and they made this their justification for the juxtaposition of different, often conflicting, moods within the same work or section of a work." 27 This style is characterized by rapid rhythms, coupled with leaps, runs, and quick tone changes. These elements help to give the melodic lines a sense of emotional instability symbolizing the nervous nature of human emotion. ${ }^{28}$ The Empfindsamer Stil reflected the Enlightenment as it was an evolution of the Doctrine of Affections. Like the Doctrine of Affections, the Empfindsamer Stil shows the importance of emotion to dictate melodies as pioneered by Descartes. However, the Empfindsamer Stil displays many emotions juxtaposed on top of one another instead of one stable emotion for an entire piece as characterized by the Doctrine of Affections. The Empfindsamer Stil helped introduce to the musical community the idea that emotions are not always centered and singular in human life. Instead of focusing on one emotion for an entire work, many emotions could be portrayed consecutively, showcasing the volatility of human emotions. ${ }^{29}$

While the Doctrine of Affections was a way of rooting emotions in reason by logically portraying one emotion or feeling per macro section, the Empfindsamer Stil was a way of basing music more purely on emotion and less on reasoning by allowing rapid changes in the character of a piece. While the former philosophy stated that emotion had to be defined and predictable, the latter showed that emotion could change quickly without reason or strict regard to proportionality. Through this change, Emanuel expanded the meaning of the Doctrine of Affections beyond a purely reasoning-based ideal to a freer, more emotionally driven ideal. ${ }^{30}$

Many of Emanuel's works, including his keyboard sonatas, quartets, and symphonies, showcase the Empfindsamer Stil. In this context, he used the Empfindsamer Stil to maintain the driving nature of melodic content in order to heighten emotion and sentiment expressed by the piece. ${ }^{31}$ While other composers used this style in Europe at the time, Emanuel

${ }^{27}$ Timothy Corrao, "C. P. E. Bach's 'Clavier Quartet in A Minor, Wotquenne 93,' Part I," Bach 12, no. 4 (October 1981): 17-18. www.jstor.org/stable /41640141.

${ }^{28}$ Brian E. Burns, "Elements of 'Empfindsamkeit' in the 'Heilig,' Wq. 217 (H. 778) of Carl Philipp Emanuel Bach." Choral Journal 46, no. 9 (March 2006):

12-13. http://www.jstor.com/stable/23556121.

${ }^{29}$ Corrao, "Clavier Quartet," 17-18.

${ }^{30}$ Cowart, "Critical Language," 23-24.

${ }^{31}$ Ibid., 19. 
was by far the most successful at its execution. With the Empfindsamer Stil, he juxtaposed various complex melodies in succession to express differing moods and mirror the unstable nature of human emotion. ${ }^{32}$ Emanuel explained the importance of emotion in music in his autobiography while discussing his favorite instrument, the clavier.

My chief effort, especially in recent years, has been directed towards both playing and composing as songfully as possible for clavier, notwithstanding its lack of sustaining power....It seems to me that music primarily must touch the heart, and the clavierist never can accomplish that through mere bluster, drumming, and arpeggiating, at least not in my opinion. ${ }^{33}$

For Emanuel, the goal of music was to directly touch human emotions by expressing feelings musically. He used emotions in the Empfindsamer Stil to give a sense of mystery to his pieces. Because of their unstable yet tuneful melodies, the music could move in directions the audience did not expect. This unease of direction helped to heighten the scattered emotions portrayed through his works. ${ }^{34}$ An obvious example of the Empfindsamer Stil in Emanuel's music can be seen in the opening of Symphony No. 5 in B Minor (Example 1).

${ }^{32}$ Corrao, "Clavier Quartet," 17-18.

${ }^{33}$ William S. Newman, "Emanuel Bach's Autobiography," Musical Quarterly 51, no. 2 (April 1965): 372. doi:10.1093/mq/li.2.363.

${ }^{34}$ Corrao, "Clavier Quartet," 18. 
Example 1: C. P. E. Bach, Symphony No. 5 in B Minor, mvt. 1, mm. $1-4 .{ }^{35}$
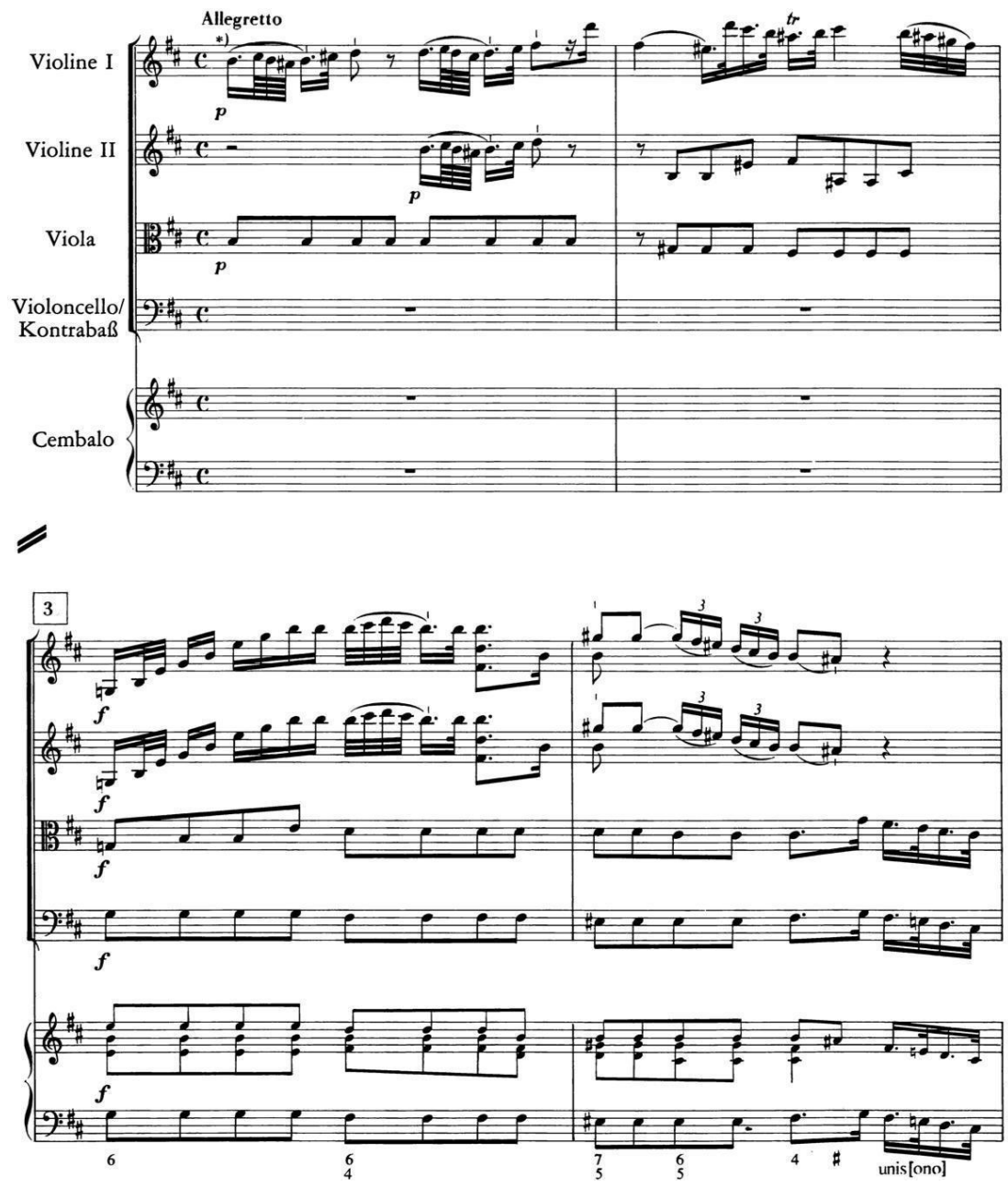

This movement begins with a dainty, yet mysterious melody in the violins in mm. 1-2 with a marked dynamic of piano and light accompaniment featuring rests in the basso and cembalo (harpsichord). With a loud accent, the third measure erupts with a rapid flow of rhythmic countermelody. This melody jumps down two octaves in the

${ }^{35}$ Carl Philipp Emanuel Bach, Symphony No. 5 in B minor, W. 182, No. 5: I. Allegretto (Frankfurt: Henry Litolff, 1976), 5. https://imslp.org/wiki /Symphony in_B_minor, H.661_(Bach,_Carl Philipp_Emanuel). 
violin part then darts back up to the register of the second measure. Starting in m. 3, Emanuel drives the piece forward with loud, steady, eighth notes in both the cello and cembalo. The sporadic interjection of this dramatic countertheme in $\mathrm{m}$. 3 startles the listener by displaying a rapid shift of emotion. If this piece had followed traditional Classical era conventions, the first theme would have been answered politely by similar thematic material. However, Emanuel utilizes the Empfindsamer Stil to create a complete juxtaposition of the listener's expectations, highlighting the instability of human emotion in music. This interjection of juxtaposed melodies recurs multiple times throughout the rest of the piece in a similar fashion, creating an unpredictably emotional movement in defiance to musical norms. ${ }^{36}$

Emanuel affirmed Enlightenment philosophy not only in his music, but also in his writings as a leading musical theorist. The primary example of his work as a musical theorist is the Versuch über die wahre Art das Clavier zu spielen. This treatise on piano technique was one of the most important and successful works of musical theory of the eighteenth century, selling over 1,000 copies in its first edition. It in many ways echoes the formulaic approach of Rameau. Emanuel was able to articulate his Enlightenment musical theory in this treatise by formalizing methods of playing keyboard instruments in a style that could properly reflect human nature and influence the emotions of the music's audience. ${ }^{37}$

In the first half of the Versuch, Emanuel explains the importance of proper fingering, quality embellishments, and a strong performance. Emanuel writes in his introduction for this section that these three factors are so fundamental that none of them could exist without the other two. ${ }^{38}$ He states this comically and with tenacity.

Owing to ignorance of these factors and their consequent absence from performance, keyboardists can be heard who after tortuous trouble have finally learned how to make their instrument sound loathsome to an enlightened listener. Their playing lacks

\footnotetext{
${ }^{36}$ Corrao, "Clavier Quartet," 18.

${ }^{37}$ Ottenberg, C. P. E. Bach, 68-69.

${ }^{38}$ Carl Philipp Emanuel Bach, Essay on the True Art of Playing Keyboard Instruments, trans. and ed. by William J. Mitchell (New York: W. W. Norton, 1949), 30.
} 
roundness, clarity, forthrightness, and in their stead one hears only hacking, thumping, and stumbling. ${ }^{39}$

The second half of the work covers the use of intervals, thoroughbass, keyboards as accompaniment instruments, and keyboard improvisation. Emanuel uses this entire section of the book to explain the importance of keyboard instruments in accompaniment. He writes, "No piece can be well performed without some form of keyboard accompaniment. Even in heavily scored works, such as operas performed out of doors, where no one would think that the harpsichord could be heard, its absence can certainly be felt." ${ }^{40}$ Through the Versuch, Emanuel gave a definite stance to the world that keyboard instruments were vital in the eighteenthcentury musical landscape and must be played in a proper way. By playing keyboard instruments correctly, the musician was able to show the correspondence between human emotion and music typified by Enlightenment musical philosophy. The Versuch stands as one of the most important eighteenth-century books on musical technique as it helps showcase the Enlightenment value of rationalizing music in order to properly display emotions through it. ${ }^{41}$

\section{The Lasting Legacy of Carl Philipp Emanuel Bach}

Regaining considerable interest within the musical community in recent years, Carl Philipp Emanuel Bach is one of the most important transitional figures in Enlightenment-era music. Emanuel was influential because of the unique combination of his distinctly German-Protestant background and a strong Enlightenment stance on musical composition. His father, J. S. Bach, taught him a great deal about music composition, the importance of music as a means to highlight scriptural truth, and the ability of music to display great beauty as was applicable to the Protestant faith. While J. S. Bach could not actively endorse music as a means of expressing human emotion due to his own religious convictions, he showed Emanuel the potential music had to deeply touch the human soul. Expanding on his father's views, Emanuel justified the expansion of music to directly express human emotions, allowing for music both inside and outside of the church to be used to deeply impact the lives and emotions of audiences worldwide.

\footnotetext{
${ }^{39}$ Bach, Essay on the True Art, 30.

${ }^{40}$ Ibid., 173.

${ }^{41}$ Corrao, "Clavier Quartet," 17.
} 
Emanuel also expanded on the philosophies of the Enlightenment, turning away from the preeminence of reason and moving toward the supremacy of emotion. Music today is heavily dependent upon emotional drive and often relies less on rational form and proportionality. During Emanuel's day, however, reason was still seen as the primary drive of music. While the Doctrine of Affections was grounded in reason and proportions, Emanuel chose to portray affections through music in a more natural and human way. His use of the Empfindsamer Stil demonstrated music's ability to portray the realistic and unpredictable nature of human emotion. Through the Empfindsamer Stil, Carl Philipp Emanuel Bach helped pioneer a new way of expressing human emotion within music, ushering in a new age of musicians and composers.

\section{Bibliography}

Bach, Carl Philipp Emanuel. Essay on the True Art of Playing Keyboard Instruments. Translated and edited by William J. Mitchell. New York: W. W. Norton, 1949.

- Symphony in B minor, W 182, No. 5: I. Allegretto. Edited by Traugott Fedtke. Frankfurt: Henry Litolff, 1976. https://imslp .org/wiki/Symphony in B minor, H.661 (Bach, Carl Philip p_Emanuel).

Bernard, Jonathan W., and Jean-Philippe Rameau. "The Principle and the Elements: Rameau's 'Controversy with D'Alembert.'" Journal of Music Theory 24, no. 1 (Spring 1980): 37-62. doi: $10.2307 / 843738$.

Bettmann, Otto L. "Bach the Rhetorician." American Scholar 55, no. 1 (Winter 1986): 113-118. http://www.jstor.org/stable/41211296.

Burns, Brian E. "Elements of 'Empfindsamkeit' in the 'Heilig,' Wq.

217 (H. 778) of Carl Philipp Emanuel Bach." Choral Journal

46, no. 9 (March 2006): 10-23. http://www.jstor.com/stable 123556121.

Corrao, Timothy. "C. P. E. Bach's 'Clavier Quartet in A Minor,

Wotquenne 93,' Part I." Bach 12, no. 4 (October 1981): 17-21. www.jstor.org/stable/41640141.

Cowart, Georgia. "Critical Language and Musical Thought in the Seventeenth and Eighteenth Centuries." College Music Symposium 27 (1987): 14-29. http://www.jstor.org/stable 140373840. 
Daymond, Emily R. "Carl Philipp Emanuel Bach." Proceedings of the Musical Association, no. 33 (1906-1907): 45-53. doi:10.1093 /jrma/33.1.45.

Frederick II. Flute Sonata in C Minor No. 84. Manuscript, ca. 17401760. https://imslp.org/wiki/Flute_Sonata_in_C_minor\%2C _SpiF_84_(Frederick_II).

Gaines, James R. Evening in the Palace of Reason: Bach Meets Frederick the Great in the Age of Enlightenment. New York: HarperCollins, 2005.

Lang, Paul Henry. "Bach: Artist and Poet." In Musicology and Performance, edited by Alfred Mann and George J. Buelow, 68-71. New Haven, CT: Yale University Press, 1997. . "The Enlightenment and Music." Eighteenth-Century Studies 1, no. 1 (Autumn 1967): 93-108. doi:10.2307/3031668.

Lim, Shiru. "Frederick the Great and Jean Le Rond D'Alembert on Philosophy, Truth, and Politics." Historical Journal 61, no. 2 (June 2018): 357-378. doi:10.1017/s0018246x17000310.

Marshall, Robert L. "Truth and Beauty: J. S. Bach at the Crossroads of Cultural History." Bach 21, no. 2 (Summer 1990): 3-14. http://www.jstor.org/stable/41640340.

Newman, William S. "Emanuel Bach's Autobiography." Musical Quarterly 51, no. 2 (April 1965): 363-372. doi:10.1093/mq /li.2.363.

Ottenberg, Hans-Günter. C. P. E. Bach. New York: Oxford University Press, 1987.

Schulenberg, David. The Music of Carl Philipp Emanuel Bach. Eastman Studies in Music. Rochester, NY: University of Rochester Press, 2014. . "Performing C. P. E. Bach: Some Questions Answered?" Early Music 41, no. 1 (February 2013): 119-122. doi:10.1093 lem/cat021.

Tiersot, Julien, and Theodore Baker. "Rameau." Musical Quarterly 14, no. 1 (January 1928): 77-107. doi:10.1093/mq/xiv.1.77. 